\title{
The Attitude of Muhammadiyah Smokers Towards Smoking Illicit (Haram) Fatwas
}

\author{
Imam Faisal Hamzah*, Zaldhi Yusuf Akbar \\ Faculty of Psychology, Universitas Muhammadiyah Purwokerto, Central Java, Indonesia \\ *Corresponding author: imamfaisalh@ump.ac.id
}

Article history: Received: 11 January 2020 Received in revised form: 28 June 2020 Accepted: 10 May 2021 Published online: 09 August 2021

\begin{abstract}
This study aims to understand the dynamics of smoking attitudes and behavior in Muhammadiyah residents. This research uses qualitative research methods by using case studies. The three informans are the management of the Regional Leader Major Islamic non Govermental Organization in Indonesia (Pimpinan Daerah Muhammadiyah - PDM) of the Banyumas region and the Muhammadiyah Tobacco Control Center (MTCC) of the Universitas Muhammadiyah Purwokerto, where three participants are smokers of Muhammadiyah residents. The study found four factors that caused Muhammadiyah residents to smoke after the issuance of the prohibited fatwa on smoking, namely the meaning of the fatwa that was still being prepared, subjective, faith that was still weak, and fatwa added more in accordance with medical assistance.
\end{abstract}

Keywords: Fatwa, Attitudes, Smokers, Muhammadiyah

(C) 2021 Penerbit UTM Press. All rights reserved

\subsection{INTRODUCTION}

The Muhammadiyah Central Leader through the Tarjih and Tajdid Assembly (2010) issued a fatwa prohibiting cigarette smoking. This is stated in fatwa NO. 6 / SM / MTT / III / 2010. The fatwa is based on the element mudharat (detrimental) for oneself and others contained in cigarettes. In addition, smokers must try to stop these actions. The policy of PP Muhammadiyah is of course with various considerations that have been reviewed by the Tarjih Assembly and Tajdid PP Muhammadiyah. Unlike Muhammadiyah, another community organization (Nahmas), Nahdatul 'Ulama (NU) (2010) who proclaimed makruh on cigarettes (may be done, but left better), one of the reasons many people depend on life for cigarette production.

What about Muhammadiyah itself? It has been eight years since the edict forbidding smoking was issued on March 8, 2010, Muhammadiyah residents who smoke are still found. The researcher conducted an initial study in 2014 by interviewing one of the leaders of the Muhammadiyah Regional Management in a large city. The interview with a interviewee was conducted at one of Muhammadiyah's institutions in the afternoon. The interviewee believe that he has practiced $99 \%$ of Muhammadiyah's teachings, but one thing that he still cannot abandon is smoking behavior. The behavior that he did from the very beginning to work was influenced by his colleagues.

The interviewee said that he was not a cigarette addict, because the speaker rarely smoked. Interviewees smoke when they gather with their neighbors or their colleagues in non-Muhammadiyah institutions. Feeling bad when his colleagues smoke and he does not. One pack of cigarettes, usually used for 14 days. The guest speaker also said that there had been a decrease in the number of smokers in Muhammadiyah, but it was not certain whether it was because of the prohibition of fatwa or there were other factors that caused the decline.

In another field study, researchers also tried to observe smoking behavior in a Muhammadiyah family. Although a father who is quite good in practicing the doctrine of kemuhammadiyahan, but his child can hardly stop smoking. Other information from researchers was obtained from fellow researchers who said that the fellow researchers were activists of Muhammadiyah activities, but did not eliminate the smoking behavior because they saw references from other mass organizations (in this case NU) as an argument.

The results of the field studies are then arranged by the researcher into a paper to be presented at a psychology seminar held by a Muhammadiyah University in Purwokerto in 2014. Researchers hope to get a response from Muhammadiyah academics themselves on the issue. The academics did not deny that this still happened in Muhammadiyah circles. This happened because there was no punishment from Muhammadiyah itself, but efforts to minimize this continued.

Four years later, researchers now work in the Muhammadiyah University of Purwokerto. Researchers can clearly observe how smoking behavior is still carried out by several employees and lecturers in the UMP environment. Quitting smoking is not an easy problem, Dinh-Williams et al. (2014) study mentioned a lower activation change in some parts of the brain when chronic smokers are given information about the dangers of smoking, so chronic smokers don't care anymore with a warning of the dangers of smoking.

The issue of smoking is not limited to individual problems, but also involves many social problems, such as economics, politics, and so on. This smoking problem eventually leads to Indonesia's political image in the eyes of the world, especially with regard to health issues. Indonesia is the only country that has not signed the FCTC (Framework Convention on Tobacco Control) in the Asia Pacific (Hutapea, 2013).

Early research studies indicate that there are differences between attitudes and behavior towards smoking policies. Attitude is a way for individuals to evaluate their social world (Baron \& Byrne, 2004). For example, agree or disagree with smoking behavior. The issue of 
this attitude is often contrary to the behavior that arises (Faturochman, 2009). For example, someone agrees with the fatwa forbidden cigarettes, but that person can not stop smoking.

Based on the description of the problem above, the researcher concludes that there are two problems. The first problem is the attitude towards the policies of Leader Center Muhammadiyah in general and the Muhammadiyah University in Purwokerto in particular. This can be categorized in the deviations of norms in organizations related to health have also been investigated by Schultz, Finega, Nykiforuk, and Kvern (2011) where his research on smoke-free regulations in hospitals in Canada is considered to be less consistent so there are still violations. Sulaiman and Bhatti (2013) call it organizational deviant.

The foregoing raises a second problem, which is the gap between attitudes and behavior in Muhammadiyah people who are still smoking. Choi, Choi, and Rifon (2010) refer to it as The Phantom Smoker, a type of "ghost smoker" who smokes but does not recognize himself as a smoker, due to a different self-identification of the smoker on him. This study aims to determine the dynamics of smoking attitudes and behavior in Muhammadiyah residents.

\subsection{LITERATURE REVIEW}

\section{Attitude}

Attitude is often equated with personality meaning, even though the two variables are different. Attitude is also interpreted by Ajzen (2005) as a way for individuals to respond to an object, person, institution, or event in a good or bad way. Other experts interpret attitudes as evaluating favorable or detrimental reactions to something or someone (often having a basis on someone's beliefs, expressed in one's feelings, and interpreted in behavior) (Myers, 2010)

Eagly and Chaiken (1993 in Judges, 2018) interpret the attitude as follows:

"Psychological tendencies expressed by manipulating an object based on the level of likes or dislikes "The conclusion of the several definitions of attitude above, namely attitude is the tendency of individuals to evaluate (like or dislike, agree or disagree) on an object. This understanding contains three main ideas in attitude, namely tendency, evaluative, and object (Hakim, 2018).

Furthermore, Hakim (2018) explains as follows: (1) tendency is a tendency towards a thing, for example a tendency towards certain politicians. (2) Evaluative is a mental process to mediate between a stimulus to its reaction. (3) The object here is an evaluation target, both abstract and concrete. It is this object that distinguishes between attitude and personality and nature (Hakim, 2018).

Aspects of attitude, explained by Faturochman (2009) include (1) affection (feeling), for example there are people who like smoking, but there are also people who do not like it. There is also an affection for something that is expressed non-verbally, for example someone covers his nose when someone is smoking next to him. (2) Then cognition (belief) can contain knowledge that becomes opni to an object, for example, people who smoke are not healthy. (3) The last is conation (behaviors that appear or are limited to tendencies), for example refusing to smoke when offered a cigarette (Faturochman, 2009).

The conclusion of the above explanation that aspects of attitude consist of mental processes consisting of affection, cognition, and conation that have a tendency as an evaluative result of an attitude object. Baron and Byrne (2004) suggest that attitudes are formed from interactions between one person and another through a series of social learning processes.

An explanation of this can be explained through classical conditioning, instrumental conditioning, and modeling. Classical conditioning occurs when individuals who are initially neutral (for example young children) then have the capacity to react to a stimulus because of the repetitive process that occurs repeatedly (Baron \& Byrne, 2004). For example, Muhammadiyah people who smoke because they have been conditioned to smoke for a long time before a fatwa was forbidden to come out. Instrumental conditioning occurs when individuals get positive reinforcement (eg. prizes) and negative reinforcement (eg. punishment) when doing something (Faturochman, 2009). For example, when a teenager smoking actually gets positive reinforcement from his friends and actually gets negative reinforcement from his parents. Positive reinforcement will be strengthened and tends to be repeated, while negative reinforcement will reduce a behavior (Baron \& Byrne, 2004).

Learning through observation (Modeling) occurs when someone learns to respond to something by seeing others respond to the same stimulus (Faturochman, 2009). For example, a teenager smokes because his parents also smoke. Although his parents forbid. The conclusion of these opinions is that attitudes can be formed through repetition, reinforcement, and observation. Wetting about attitude cannot be separated from wetting about behavior, because there are often inconsistencies between the two (Faturochman, 2009).

The judge (2018) conveyed the ideas of Ajzen and Fihsbein (1975) in the Theory of Reasonable Behavior which states that attitudes will become behavior if there is an intention or intention, namely the decision to behave in a certain way. This opinion was later revised by Ajzen (1975 in Judge, 2018) by proposing a Theory of Planned Behavior which included a control factor for behavior. For example, someone wants to stop smoking, but because it has become an addiction, the control of the behavior will decrease. The conclusion is that attitude can be a behavior depends on factors of intention or intention and also control of behavior.

\subsection{METHODOLOGY}

This study uses a qualitative research method with a case study approach, in which case studies are based on the study of human behavior that is idiographic, namely the study of human behavior that is individual, not nomothetic which is more legal in general (Smith, 2011). Yin (2011) states that case studies are empirical investigations of phenomena in a real-life context where the boundary between the two (phenomena and context) seems unclear so that multi-source evidence is needed. Case studies are also an approach that can be used to study public policy (Stake, 2000). 
Respondents

The author uses two informants who played a role in the implementation of the fatwa on illicit cigarettes in the Banyumas region and an additional informant as a complement to the data. The first informant is the chairperson of Banyumas Regional Leader Major Islamic non Govermental Organization in Indonesia (PDM) in which the author gives the initials "H", the second informant is the organizer of the Banyumas Regional Leader Major Islamic non Govermental Organization in Indonesia (PDM) tarjih and tajdid which the writer conveys with the initials "K", while the third informant is the informant outside the Regional Leader Major Islamic non Govermental Organization in Indonesia (PDM) Banyumas management who is the comparison and the Regional Leader Major Islamic non Govermental Organization in Indonesia (PDM) Banyumas management cadre and the author conveys the initials "K", while the third informant is the informant outside the Regional Leader Major Islamic non Govermental Organization in Indonesia (PDM) Banyumas management complete the data related to the implementation of the fatwa forbidden smoking in the Banyumas region where the author initials " $\mathrm{P}$ " which is a board of Muhammadiyah Tobaco Control Center (MTCC) University of Muhammadiyah Purwokerto (UMP).

\section{Ethics in Research}

Edwards \& Holland (2013) stated that in interview, there are several ethics that the researcher have to stressed on as a professional researcher, which is the research cannot endanger respondent, and have to protect the respondent from any form or risk and exploitation during the research still going. The researcher ensure that they got a formal letter from the faculty of university before executing the research. Researcher also provide informed consent form and get the agreement from the respondents before conducting the interview session.

Researchers had informed to the respondents that their participation is free and they can withdraw themselves from the research in anytime even it could disrupt the research (Leach et al., 2012). This ethic gives right to respondent to withdraw, either from the early session, middle session, or at the end of session. Besides that, throughout the research, the researchers responsible in protecting themselves during the interview session by doing early planning before meeting the respondents (Maruster, 2013). Researchers and respondent went through the interview in open space and safe for both parties.

\subsection{DISCUSSION AND RECOMMENDATION}

Researchers concluded that there was a desire of the participants to be able to stop smoking for a variety of reasons. Intention, motivation, and efforts to stop smoking become important capital. Unlawful fatwa that emphasizes health factors is apparently not a strong reason for someone to stop smoking, but it should also be noted that a person's socioeconomic factors. The common thread was the findings of informants and participants.

"Ya mereka punya pendapat sendiri-sendiri. Kecuali mereka karyawan yang baru merokoknya kadang-kadang kemudian saya kaitkan dengan faktor ekonomi lah mereka sadar, itu lebih ampuh. Karena secara real mereka lebih tau. Untuk makan sekian kalo saya merokok sekian, yang jelas seperti itu, lebih mantep." (Informan C, 120)

Yes, they have their own opinions. Except for employees, they are new to smoking sometimes, then I relate to their economic factors, it is more powerful. Because they actually know better, how much it costs to eat, how much it costs if I smoke, which is clear, the better." (Informant C, 120)

Researchers tried to draw a common thread from the findings obtained from informants and participants. Problems related to smoking behavior of Muhammadiyah residents after the issuance of illicit fatwas on cigarettes are caused by several factors. The first is related to the meaning of the fatwa itself. Researchers found differences in perception related to the meaning of the fatwa itself. Is it a norm that must be obeyed or just a suggestion that does not cause consequences. If the fatwa is a recommendation, it means someone will choose a stimulus that is considered more positive. In addition, the lack of negative consequences of the norm is considered to be a loophole for violations.

"ya walaupun saya tahu efeknya mungkin tidak terlalu banyak bagi kesehatan tetapi itu tidak baik gitu, dibandingkan kita katakanlah minum softdrink nih kira-kira softdrink kan enak kaya minum Fanta, kadar gulanya tinggi seberapa banyak orangorang yang terkena gula darah tinggi dibanding dengan orang yang terkena kanker paru-paru kan misalnya seperti itu, hal itu buruk saya pengin menghindari tapi itu hmm ya ini berproseslah istilahnya" (Partisipan R, 36)

"yes even though I know the effect may not be too much for health but it's not that good. Compared to us, let's say that drinking soft drinks is something that soft drinks are delicious, like drinking Fanta, the sugar levels are high, how many people get high blood sugar compared to people with lung cancer, for example like that, it's bad I want to avoid it but that hmm yes this is processing the term" (Participant R, 36)

Second, the issue of faith. The spirituality aspect has a role to play with one's obedience to fatwa as the norm. The participants understood that the fatwa had a spiritual dimension. For example a violation of an unlawful fatwa can lead to the consequences of sin, but the findings of the researchers show that fatwa outreach more emphasizes physical depravity or health. This is also the third problem, namely the emphasis of fatwa which focuses more on health issues, compared to other aspects such as spirituality and economics and social.

"Saya yang mungkin secara keimanan belum bagus gitu, jangankan fatwa Muhammadiyah yang mengarah ke mengkharamkan rokok, mungkin larangan-larangan Tuhan kita Allah SWT saja mungkin saya sebagai manusia biasa kadang masih hmm berani melanggar gitu yah," (Participan F,30) 
"I may not have a good faith, let alone the Muhammadiyah fatwa that leads to the prohibition of smoking, maybe the prohibitions of our God, Allah SWT, maybe I, as an ordinary human being, sometimes still dare to violate that, right?" (Participant F, 30)

Attitude is an evaluative effort of a person towards an object to be positively or negatively addressed. The problem is, attitudes are often not consistent with the behavior displayed by someone (Faturochman, 2009). Participants in this study might agree with the smoking prohibition fatwa, but the behavior displayed is the opposite, which is still smoking. Ajzen (2012) states that the intention (intention) is to be a moderator between attitudes and behavior in which the assumed change of intention will also be followed by behavior change.

Furthermore Ajzen (2012) also explains that intentions are formulations of subjective norms and perceptions of attitude objects. Individual perceptions of fatwas and smoking itself will determine the intention that will manifest in behavior. Subjective norms are associated with evaluations that one perceives of others to support their attitudes and behavior. For example, Muhammadiyah smokers consider that the norms of Muhammadiyah are not in accordance with their attitude, so they will look for the views of others who will support their attitude.

The problem when viewed from the theory of prospects Daniel Kahneman (2011) said that the negative consequences of someone who loses something (loss) is far more psychological impact than when they get it (gain). In the case of Muhammadiyah people who still smoke perceive negative consequences obtained from the fatwa are not comparable with the positive consequences caused by smoke. In this study, negative consequences that are more influential are economic and social factors. Wasteful to be a reason for participants to stop meorkok. In addition, social factors such as having children or grandchildren also influence to stop or reduce the intention to smoke.

A public policy in the perspective of Islam is a policy that contains maslahat which is bound by shari'ah through the arguments of shari'i, so it is not measured by passion (Mustofa, 2015). A policy maker should have the capacity as a leader who has the knowledge to direct it so that it can put things in the right place (Al-Attas, 2001).

As indicated by Shafir (2013), a policy should be able to understand individual behavior well. Therefore, a policymaker also needs to have his own behavioral science, but in Islam, behavioral issues must have an appropriate worldview. Zarkasyi (2018) said that the Worldview of Islam has the characteristics of faith in God. Faith in God, in Islam, cannot be separated from science (Ismail, 2016) and science is the fruit of reason that distinguishes humans from other creatures (Khaldun, 2013).

the limitation of this research is the variation in the background of participants who are still lacking (two doctors and one employee) so that they still need more comprehensive data to obtain more in-depth results. the data also needs to be reconfirmed with related parties so that the data is stronger.

\subsection{CONCLUSION}

The researcher concludes that there are several factors that influence the attitude of Muhammadiyah members who are still smoking after the issuance of a prohibited fatwa on cigarettes. The meaning of fatwa is still perceived subjectively, faith is still weak, and fatwa emphasis is more dominated by medical issues. The implementation of the cigarette haram fatwa policy should adjust to individual needs. Each individual has different needs to stop smoking, both for economic and social reasons. Further research needs to further explore this issue with participants who are more diverse in their background activities at the Charitable Enterprises Muhammadiyah (AUM).

\section{References}

Baron, R.A. \& Byrne, D. (2004). Social Psychology Volume 1 (Translator: Djuwita, R., Parman, M.M., Yasmina, D., \& Lunanta, S.P.). Jakarta: Erlangga Publisher. Choi, Y., Choi, S.M., dan Rifon, N. (2010). "I Smoke but I Am Not a Smoker": Phantom Smokers and the Discrepancy Between Self-identity and Behavior. Journal of American College Health, 59(2), 117-125.

Edwards, R. \& Holland, J. (2013). What is Qualitative Interviewing? The 'What is?' Research MethodsSeries. Edinburgh: A\&C Black

Faturochman (2009). Introduction to Social Psychology. Yogyakarta: Library Publisher.

Hakim, M.A. (2018). Attitude. In Pitaloka, A., Abidin, Z., \& Milla, M.N. (Eds). Social Psychology: Introduction to Theory \& Research. Jakarta: Salemba Humanika. Ismail, M.Z. (2016). Aqal in Islam: An Overview of Epistemology. Kuala Lumpur: Malaysian Institute of Islamic Understanding.

Kahneman, D. (2011). Thinking Fast and Slow. London: Penguin Books.

Leach, M. M., et al. (2012). The Oxford Handbook of International Psychological Ethics. Oxford:Oxford University Press

Majlis Tarjih dan Tajdid Pimpinan Pusat Muhammadiyah. (2010). Fatwa Majelis Tarjih dan Tajdid Pimpinan Pusat Muhammadiyah No.6/Sm/Mtt/Iii/2010 Tentang Hukum Merokok. Retrieved from http://tarjih.muhammadiyah.or.id/download-fatwa-219.html. Retrieved date: 10 January 2020.

Maruster, L. (2013). Qualitative Research Methods. Newcastle: SAGE.

NU Online. (2010). PBNU Tak Sepakat Fatwa Haram Rokok Muhammadiyah. Retrieved from http://www.nu.or.id/a,public-m,dinamic-s,detail-ids,1-id,22939-lang,idc,warta-t,PBNU+Tak+Sepakat+Fatwa+Haram+Rokok+ Muhamma diyah- phpx. Retrieved date: 10 January 2020.

Shafir, E. (2013). Introduction. In Shafir, E. (Ed.) The Behavioral Foundation of Public Policy. Princeton: Princeton University Press.

Zarkasyi, H.F. (2018). Foreword. In Muslih, M.K. (Ed.). Worldview Islam: Discussion of Important Concepts in Islam. Ponorogo: Science Islamization Center (PII) and Unida Gontor Press. 